DOI : 10.24260/khatulistiwa.v9i1.1269

\title{
ISLAMIC INTEGRATION AND TOLERANCE IN COMMUNITY BEHAVIOUR; MULTICULTURALISM MODEL IN THE REJANG LEBONG DISTRICT
}

\author{
Idi Warsah', Dewi Cahyani ${ }^{2}$ and Rahmi Pratiwi ${ }^{3}$ \\ Curup Islamic State Institute (IAIN), Bengkulu \\ 1 $\underline{\text { idiwarsah@iaincurup.ac.id; }} 2$ and 3
}

\section{HIGHLIGH}

- $\quad$ Rejang Lebong community adhered to the foundation of the Indonesian State namely Pancasila and Bhineka Tunggal Ika, besides that there were also relics from their ancestors namely the Rejang Pat Petulai tribe, a symbol of multiculturalism.

\begin{tabular}{|c|c|c|}
\hline \multicolumn{3}{|c|}{ ARTICLE HISTORY } \\
\hline Submitt & & 05 Mar 2019 \\
\hline Revision & : & 24 Feb 2019 \\
\hline Revision & : & 2 Mar 2019 \\
\hline Minor & & \\
\hline Accepted & : & 5 Mar 2019 \\
\hline Published & : & 30 Mar 2019 \\
\hline
\end{tabular}

Keyword :

KHATULISTIWA: Journal of Islamic Studies Vol. 9, No. 1. March 2019

\begin{abstract}
Culture, religion, ethnic, and language diversity are wealth and pride of Indonesian people. It raises the discourse of multiculturalism as a solution. Taking apart from the pros and cons of this discourse as a Western discourse, authors assert that multiculturalism in the Islamic perspective is the sunnatullah and the fact that it cannot be denied. The descriptive study used to describe the tolerance by the Rejang lebong community and the values derived from Islam and the awareness of Multiculturalism. The results show that there is a link between Islam, nationality and diversity, framed in a multicultural model of social life in Rejang Lebong that adheres to religious values, the philosophy of Pancasila and Bhineka Tunggal Ika, and the philosophy of their ancestors, that is Rejang Pat Petulai which is a symbol of community in unity.

Islamic value integration, religion, community.
\end{abstract}

(C)2019 Khatulistiwa All Rights Reserved

DOI:

Islamic Integration and Tolerance in Comuunity Behaviour; Multiculturalism Model in The Rejang Lebong District 


\section{A. INTRODUCTION}

Indonesia is one of the largest multicultural countries in the world, because the socio-cultural and geographical conditions that are so diverse and broad cause Indonesia to be a multi-ethnic, multi-racial, multi-cultural and multi-religious country. Its vast territory consisting of thousands of islands, the diversity of cultures, tribes, races and religions is a wealth that this nation has. Cultural diversity by the community is commonly called multicultural. This pluralism according to Azra is a blessing in disguise for the Indonesian people. Therefore managing diversity is truly caring for Indonesia. In Suparlan's records there are approximately 500 ethnic groups that inhabit the territory of Indonesia from Aceh Province to Papua. This diversity requires the cultural plurality, because it is indeed to a historical necessity for the Indonesian people. The motto of Bhineka Tunggal Ika actually reflects this plurality, and at the same time, it contains the ideals as defense for diversity as wealth and strength (Mustafa, 2014).

Multiculturalism is a cultural equality. Each human culture or ethnic group must be positioned equally. There is nothing higher and nothing is more dominant. Seeing this term, multiculturalism means wanting to foster an attitude of doubt or skepticism so that there is only relative. Then also Syafiq A. Mughni in the introduction to the book Multicultural Education said "every civilization and culture that exists is in a position that is equal. There is no higher or superior culture from other cultures. Such expressions must be addressed wisely (Rahman, 2014).

Such a statement certainly contradicts the claim of Islam as the only truth, and the prophetic tradition that calls on other religions to Islam. However, Islam upholds tolerance, even in the history of Islamic civilization, Jews, Christians, Magi and other religions have lived peacefully under the auspices of the Islamic state.

KHATULISTIWA: Journal of Islamic Studies Vol. 9, No. 1. March 2019
DOI:

Islamic Integration and Tolerance in Comuunity Behaviour; Multiculturalism Model in The Rejang Lebong District 
Islam is a universal religion that upholds human values, equality and recognizes the diversity of cultural and pluralistic backgrounds. Multicultural according to Islam is a rule of God (sunnatullah) that will not change, nor can it be resisted or denied. Everyone will face pluralism wherever and whenever He or She is. This statement illustrates that Islam highly respects multiculturalism because Islam is a religion that expressly recognizes the differences between individuals to live together and respect one another (Mustafa, 2014).

This indicates that Islam is very concerned with tolerance among people, both different ethnicities, races, ethnicities and religions because Islam is a peace-loving religion. Doctrinally, tolerance is fully required in Islam. Islam is a religion of peace and is a religion that is rahmatal lil alamin (a religion that nurtures all nature). This means that Islam is not to erase all existing religions. Islam offers dialogue and tolerance in the form of mutual respect. Islam realizes the diversity of mankind in religion and belief is God's will because it cannot be equated.

Today, multiculturalism is an issue that discussed warmly in various scientific perspectives: from the point of view of education, psychology, sociology, anthropology, and also Islamic law. In this paper, the multiculturalism will dialogued with the Islamic perspective then linked to tolerance between people who focus on one particular area, Rejang Lebong Regency.

Indonesia which consists of many islands has many tribes and customs. Likewise, the Rejang Lebong Regency has various tribes and races, one of which is worthy of research. The question that becomes the basis is why was the Rejang Lebong District chosen in this study? The reason is that Rejang Lebong Regency has many tribes, races, cultures, ethnicities, and religions. However, the level of tolerance in Rejang Lebong Regency is high. It is evident that in this region the Vihara was built as a place of Buddhist worship amidst the crowds of Muslims.

KHATULISTIWA: Journal of Islamic Studies Vol. 9, No. 1. March 2019
DOI:

Islamic Integration and Tolerance in Comuunity Behaviour; Multiculturalism Model in The Rejang Lebong District 
It was noted that the native inhabitants of Rejang Lebong Regency consisted of Rejang and Lembak ethnics. Rejang ethnic inhabited in Curup District, Curup Utara, Curup Timur, Curup Selatan, Curup Tengah, Bermani Ulu, Bermani Ulu Raya, and Selupu Rejang. Lembak Ethnic inhabits in Padang District, Padang Ulak Tanding, Binduriang, Sindang Dataran, Sindang Beliti Ulu, Sindang Beliti Ilir, and Sindang Kelingi (Windiantari, 2012). Besides ethnic Rejang and Lembak, this region is inhabited by immigrant ethnic groups such as Javanese, Minangkabau, Sundanese, Batak, Palembang and Chinese. Ethnic Javanese are the largest ethnic group of diverse ethnic migrants, who initially arrived as transmigrants (Devi, 2016).

The Rejang Lebong community adheres to various religions, consisting of Islam, Catholicism, Protestantism, Hinduism and Buddhism. The percentage of followers of religion is as follows: Islam $97.60 \%$, Protestant $0.61 \%$, Catholic $1.30 \%$ and Buddha 0.30\% (Lebong D. R., 2018) The followers of religions other than Islam as a whole are immigrants from various ethnic groups, including: Javanese, Balinese, Batak and Chinese descendants. Each religious adherent has 561 places of worship consisting of each religion. (Lebong D. R., 2016) Through these data, it can be seen that Islam is the majority religion adopted by indigenous people in Lebong Rejang Regency.

Based on the above-mentioned explanation, it implies that in this study the focus is to see why existing or multicultural differences in Rejang Lebong Regency can unite the community and can form a high tolerance in community life. This paper also tries to see universal ideas in social life as the foundation for society in forming tolerance among existing multicultural differences.

Based on the background of the problem and the description of the focus above which explains that multiculturalism in Rejang Lebong Regency can unite the community and can form tolerance in daily life. So, the formulation of the problems posed in this study are as follows: What are the factors that influence the community

KHATULISTIWA: Journal of Islamic Studies Vol. 9, No. 1. March 2019
DOI:

Islamic Integration and Tolerance in Comuunity Behaviour; Multiculturalism Model in The Rejang Lebong District 
in Rejang Lebong uphold the meaning of tolerance in a community?; How to manage the values of multiculturalism in Rejang Lebong District so that it can form a character of tolerance between people ?; How does Islam integrate the values of multiculturalism in community life?

\section{B. METHOD}

This study uses a qualitative approach. According to Bogdan and Taylor, qualitative research is one of the research procedures that produces descriptive data in the form of speech or writing and the behavior of the people observed. The qualitative approach is expected to be able to produce in-depth descriptions of speech, writing or observable behavior (Moleong, 2013).

According to Creswell in Setyosari, qualitative research is an approach or search to explore and understand a central phenomenon. To understand the central level the researcher interviewed the study participants or participants by asking general and broad questions. Information in the form of words or texts submitted by participants will be collected. Data in the form of words or texts are then analyzed, the results of the analysis can be in the form of descriptions or descriptions or can be in the form of themes. From these data, the researcher makes an interpretation to capture the deepest meaning (Setyosari, 2016).

The location of this study is Rejang Lebong Regency, located in Bengkulu Province, South Sumatra Island. The reason for choosing this location is because the people in Rejang Lebong have a high level of tolerance in living in a society even though it has a diversity of tribes, cultures, and religions so that it rarely raises conflicts between communities. On this basis, this location was chosen to conduct the research. The source of research data is the subject from which the data was obtained. For this study, the data sources used were sources of data originating from informants, namely religious or customary figures in Rejang Lebong district. Data

KHATULISTIWA: Journal of Islamic Studies Vol. 9, No. 1. March 2019
DOI:

Islamic Integration and Tolerance in Comuunity Behaviour; Multiculturalism Model in The Rejang Lebong District 
collection techniques used in this study were observation, interviews, and literature studies.

\section{RESULT AND DISCUSSION}

The term multiculturalism is simply interpreted as "cultural diversity". There are three terms commonly used to describe good diversity based on religion, race, ethnicity, language, and culture, namely plurality, diversity and multicultural (Anan, 2016). However all of them do not have the same connotation. Multiculturalism is understood as a system of beliefs and behaviors that recognize and respect the existence of all different groups within an organization or society, recognize and respect socio-cultural differences, encourage and enable their sustainable contribution in an inclusive cultural context that empowers all within an organization or society (Rusli, 2012).

Multiculturalism can also be interpreted as "an intellectual social movement that elevates the value of difference as a core principle and emphasizes that all cultural groups must be treated with respect and equality. Thus, each individual feels equal in his/her community.

Furthermore, it was emphasized that multiculturalism is an ideology that glorifies cultural differences or a belief that recognizes cultural pluralism as a lifestyle of society. Multiculturalism will be a bridge that accommodates ethnic and cultural differences in a pluralistic society (Syahril, 2013).

Multiculturalism in the broader terminology and accepted in contemporary needs is that all humans from a variety of varied cultures permanently live side by side, in addition to many versions of multiculturalism emphasizing the importance of the study of other cultures, trying to understand them fully and empathically. On the other hand, multiculturalism implies a necessity to appreciate other cultures. Furthermore, it is emphasized that multiculturalism arises wherever when it is

KHATULISTIWA: Journal of Islamic Studies Vol. 9, No. 1. March 2019
DOI:

Islamic Integration and Tolerance in Comuunity Behaviour; Multiculturalism Model in The Rejang Lebong District 
studied and the diaspora that live from it become urgent, and this requires mutual adaptation, so that groups progress from material and manufacturing and cultural exchanges in the form of ideas from various parts of the world (Syahril, 2013).

Philosophically, multiculturalism departs from assumptions about human glory and honor (human dignity). And this principle is found in all major world religions. Because human beings have a noble position, the rights inherent in them must be respected and maintained. Blasphemy and violation of these human rights is the oppression of universal humanity. So, any differences that occur do not lead to conflicts that can injure human rights. For that reason, tolerance is a necessity to respect these differences, by means of dialogue and eliminating discrimination and prejudice in association (Rusli, 2012).

As a paradigm, multiculturalism contains ethical values, which are the basic guidelines in each individual behavior. In the guideline there are moral principles that guarantee each individual and community activity in accordance with their rights and obligations. These moral principles include politics and democracy, justice and law enforcement, employment and business opportunities, human rights, cultural rights of minority communities and groups, and others. Therefore, multiculturalism can be said as an ethical movement (Rusli, 2012).

In responding to the existence and diversity of culture, ethnicity, nation, language, religion and so on, Islam offers a conception of tolerance. Tolerance presupposes a sense of mutual respect and respect with one another while upholding a sense of unity and brotherhood to realize a peaceful and happy life. Etymologically, the tolerance term comes from tolerantie Dutch whose verb is tolerant. (Syahril, 2013) Tolerance comes from English tolerantion, whose verb is tolerate and comes from Latin, tolerare which means restraint, patience, letting others down, and being cautious about different opinions. Furthermore, it was explained that tolerance contains the meaning: to respect the establishment that is different from one's own.

KHATULISTIWA: Journal of Islamic Studies Vol. 9, No. 1. March 2019
DOI:

Islamic Integration and Tolerance in Comuunity Behaviour; Multiculturalism Model in The Rejang Lebong District 
Observing this context, tolerance is an attitude of tolerance to each other, and even appreciates the understanding that is different from the ideology that is adopted by itself the willingness to respect different understandings of the ideas that are adopted by themselves.

According to Umar Hasyim, tolerance is defined as granting freedom to fellow human beings or to all citizens of society to carry out their beliefs or rules of life in determining their own destiny, as long as they carry out and determine their attitudes and they do not violate and do not conflict with the basic conditions of the creation of order and community peace (Yassir, 2014).

In Arabic, tolerance is denoted by the word tasamuh, which means an attitude of letting, roomyness, generosity, and charity. With that in mind, tolerance means respecting the beliefs or culture of another person or group patiently and consciously. And it should be noted that tolerance does not mean participating in justifying the beliefs or beliefs of others, but rather than respecting the human rights that exist in other people, even if they differ from their beliefs.

On the other hand, Islam does not teach the attitude of individualism and does not justify excessive fanaticism. On the contrary, Islam teaches togetherness and otherness and even upholds brotherhood among others. Therefore, there is no reason quarrel each other. Islam strongly encourages its people to behave politely between them, to form a community that is mutually cooperative. From here, a sense of security will appear on the face of the earth (Syahril, 2013).

\section{Objectives of Rejang Lebong Regency Population}

The population of Rejang Lebong numbered 253,681 people, consisting of 62,021 heads of households, 127,845 men and 125. 836 women spread over 15 districts, 124 villages and 31 sub-villages. The population density is 171 people every $1 \mathrm{~km}$. Curup Kota (City) District is the most densely populated sub-district with a

KHATULISTIWA: Journal of Islamic Studies Vol. 9, No. 1. March 2019
DOI:

Islamic Integration and Tolerance in Comuunity Behaviour; Multiculturalism Model in The Rejang Lebong District 
population density of 241.8 per $\mathrm{km}$ (Lebong K. S., 2016). With this figure the population density of Rejang Lebong is relatively low. This is not much different situation from other districts in Bengkulu.

The $83 \%$ of Rejang Lebong residents live in the countryside. The native population consists of ethnic Rejang and ethnic Lembak, ethnic Rejang inhabit Curup District, Curup Utara, Curup Timur, Curup Selatan, Curup Tengah, Bermani Ulu, Bermani Ulu Raya, and Selupu Rejang. Lembak ethnic groups inhabit Padang City District, Padang Ulak Tanding, Binduriang, Sindang Dataran, Sindang Beliti Ulu, Sindang Beliti Ilir, and Sindang Kelingi.

The indigenous population, supporting the oldest culture in Bengkulu consists of three major tribes namely; Malay tribes, mostly residing in the Municipality of Bengkulu. The Rejang tribe is spread in Rejang Lebong Regency and North Bengkulu. the Serawai tribe inhabits South Bengkulu Regency and Enggano Island. (Nusantara, 1992) The social perception of the Bengkulu community when referring to the Rejang tribe (tun jang) has the connotation of the Rejang people who lived in Rejang and in Lebong. While the Rejang tribe who lived in the North Bengkulu and Kepahyang is called Rejang Utara and Rejang Kepahyang.

The Rejang tribe inhabits four regencies namely Rejang Lebong, Lebong, kepahyang and North Bengkulu (Arga Makmur). The Rejang tribe is divided into these four regions which is called "Rejang Empat Petulai". The Malays and Serawai who settled in these three regions were considered as migrants, as well as other tribes from outside Bengkulu such as Java, Minangkabau, Sunada, Batak and others (Irsal, 2017).

The Rejang Lebong community adheres to various religions, consisting of Islam, Catholicism, Protestantism, Hinduism and Buddhism. The percentage of adherents of religion is as follows: Islam is $97.60 \%$, Protestant is $0.61 \%$, Catholic is $1.30 \%$ and Buddhism is $0.30 \%$. The existence of religions is from immigrants from

KHATULISTIWA: Journal of Islamic Studies Vol. 9, No. 1. March 2019
DOI:

Islamic Integration and Tolerance in Comuunity Behaviour; Multiculturalism Model in The Rejang Lebong District 
various ethnic groups, including: Java, Bali, batak and Chinese descent. There are has 561 places of worship consisting of each religion (Lebong D. R., 2016).

\section{Significance of Tolerance in Community Life in Rejang Lebong}

Tolerance is very important in human life, both in speech and in behavior. In this case, tolerance means respecting and learning from others, respecting differences, bridging cultural gaps, so that attitudes are similar. Tolerance is also the beginning of the attitude of accepting that differences are not wrong, precisely differences must be valued and understood as wealth, for example differences in race, ethnicity, religion, customs, perspectives, behavior, opinions and so forth. With these differences, it is expected that humans can have tolerance towards all the differences that exist, and try to live in harmony, both individuals with individuals, individuals with community groups, and community groups with other community groups.

Based on the results of interviews with one of the religious / traditional leaders in Rejang Lebong, the people in Rejang Lebong highly uphold tolerance in their lives, for example by respecting ethnic, interfaith, intercultural, and inter-linguistic values. This is based on the values of the foundation of the State of Indonesia, namely Pancasila (Sahab, 2017).

One of the values of Pancasila relating to tolerance in life is the third principle that reads "Indonesian Unity", there is a unity value that has meaning even though Indonesia is an archipelagic country and it is inhabited by various ethnic group division. In the value of unity also contained the value of patriotism and love of the homeland, where all Indonesian people must unite and will to sacrifice for their beloved homeland.

The Implementations of the value of unity: the placing the unity of interests of

the nation and state and the safety of the nation and state above personal or group interests. Besides that, they have to have willing to sacrifice for the sake of the nation

KHATULISTIWA: Journal of Islamic Studies Vol. 9, No. 1. March 2019
DOI:

Islamic Integration and Tolerance in Comuunity Behaviour; Multiculturalism Model in The Rejang Lebong District 
and state, love the homeland and the nation. They also have to be proud to have a nation of Indonesia.

Apart from the value of the Pancasila, tolerance can also be taken from the various single motto ika, namely "different but still one". (Sahab, 2017) In depth Bhineka Tunggal Ika has meaning even though in Indonesia there are many tribes, religions, races, arts, customs, languages, and so on but still a single unit of nationality. Combined with flags, national anthems, currencies, languages and others, the meaning of singular misunderstanding ika implies that even though Indonesia has diverse cultures and customs, the whole is a unity. This indicates that the unique meaning of ika is to call on the Indonesian people to be tolerant in social life. In addition, there are inheritance in Rejang Lebong such as "Rejang Pat Petulai" which upholds the meaning of tolerance and as a proof of unity and unity. The tradition of patriarchal origin originating from ancestors is still preserved today (Sahab, 2017).

\section{Management of Multiculturalism Values in Rejang Lebong District}

Multiculturalism can be formulated simply as a value system or policy that respects diversity in a society based on the willingness to accept and appreciate the existence of other groups that are different in ethnicity, gender or religion. This certainly has values that are considered to be good. These values include:

First, Tolerance: Tolerance presupposes a sense of mutual respect and respect with each other while upholding a sense of unity and brotherhood in order to realize a peaceful and happy life.

Second, Deliberation: In the concept of Islam, if there is friction (disputes ) between one another, the path of peace can be pursued through dialogue (deliberation). Dialogue (deliberation) is not merely a conversation, but more than that, dialogue is a meeting of two minds and hearts related to common problems, with a commitment to learn from each other so that they can change, grow and develop.

KHATULISTIWA: Journal of Islamic Studies Vol. 9, No. 1. March 2019
DOI:

Islamic Integration and Tolerance in Comuunity Behaviour; Multiculturalism Model in The Rejang Lebong District 
Third, Please Help: Help or help is a necessity of human life that cannot be denied. The fact has proven that a job or anything that requires another party will definitely not be done alone by the person concerned even though he is a person who has the ability and knowledge about it. This shows that helping each other is a necessity in human life. There is no one in this world, can live with solitude, without contact and help from others. By reviving the tradition please help, the community will be able to construct a sturdy and resilient building of civilization. Of course if the help activity is done in terms of kindness, not in immorality, violation and hostility.

Fourth, Shilaturahim: Etymologically, shilaturrahim comes from two Arabic words, namely silah and al-rahm. The word silah means connection, relationship, or bond, and ar-rahm means womb, relatives or family. The word ar-rahm is also interpreted with love. Terminologically, shilaturrahim is to connect the kinship with sincerity and compassion. But in general, friendship can be interpreted by connecting brotherhood with fellow humans without seeing the differences between them. The diversity that exists in the community will be reflected in the presence of friendship. Silaturrahim does not only eliminate the partition and difference, but it can also foster a sense of affection among others, open the door to sustenance and prolong life (Syahril, 2013).

Fifth, Brotherhood: The very noble teachings of Islam related to multiculturalism are brotherhood (al-ukhuwwah). On the other hand, brotherhood is a great teaching that deserves to be developed to reach togetherness and otherness. At the beginning of the Prophet in Medina, one of the agendas carried out was to enforce mu'akhah (brotherhood) among others.

These values are used as a basis by the community in Rejang Lebong to carry out community life in the presence of multiculturalism. Plus, there are many villages in Rejang Lebong where the community is still close with family, so the value of tolerance is highly upheld by them. The way to manage these values is for example by

KHATULISTIWA: Journal of Islamic Studies Vol. 9, No. 1. March 2019
DOI:

Islamic Integration and Tolerance in Comuunity Behaviour; Multiculturalism Model in The Rejang Lebong District 
deliberating a dispute, helping each other to help and work together to help others (Sahab, 2017).

\section{Integration of Islam against the values of multiculturalism}

The existence and history of multicultural people is a treasure of knowledge for Muslims to be studied more deeply and comprehensively. The differences that arise around human life have been illustrated in the Qur'an, including the following:

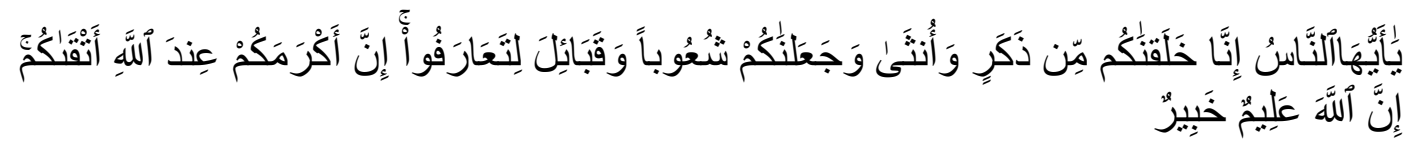

O mankind, indeed We have created you from male and female and made you peoples and tribes that you may know one another. Indeed, the most noble of you in the sight of Allah is the most righteous of you. Indeed, Allah is Knowing and Acquainted (QS. Al-Hujurat (49): 13).

According to Ibn Kathir, the verse above confirms that all humans when viewed from the element of occurrence, namely clay, up to Adam and Eve are the same. Indeed, the difference in their superiority is because of religious matters, namely obedience to Allah and His Messenger. That's why after prohibiting acts of gossiping and insulting others. Allah said, reminding them in this verse, that humans have the same dignity (Ad-Dimasyqi, 2012).

Meanwhile according to Shihab, said Syu'ub, which is the plural form of the word sya'b. this word is used to denote a collection of tribes that refer to one grandfather. The tribe consists of many family groups called umarah (Shihab, 2002).

This verse according to the narrators of the Mufassirun substantially confirms the diversity of mankind from various sides. Term syu'ub waqaba'il (national and tribal) in the context of the al-Qur'an was revealed to reflect geographical diversity of humans.

KHATULISTIWA: Journal of Islamic Studies Vol. 9, No. 1. March 2019
DOI:

Islamic Integration and Tolerance in Comuunity Behaviour; Multiculturalism Model in The Rejang Lebong District 
In response to this diversity, the Qur'an provides signs of life, including not imposing the will of others on certain aspects. Allah SWT said:

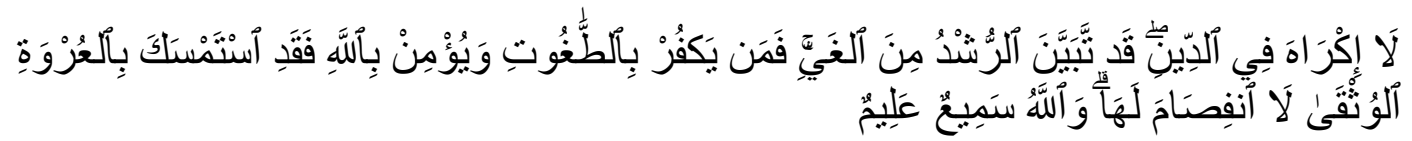

There shall be no compulsion in [acceptance of] the religion. The right course has become clear from the wrong. So whoever disbelieves in Taghut and believes in Allah has grasped the most trustworthy handhold with no break in it. And Allah is Hearing and Knowing QS. Al-Baqarah (2): 256).

Some of the verses of the Qur'an above all speak of multiculturalism in a context that is more relevant and accepted for contemporary needs; that all human beings from various cultures permanently live side by side based on rahmah, musyawarah, ta'aruf and tasamuh, so that three aspects of mutualism can be built, namely mutual trust, understanding and respect (Syahril, 2013).

Thus, the awareness of difference is a mercy, and it can be reflected in tolerance in the Rejang Lebong community. Some people are participating in other people's religious rituals under the pretext of tolerance. This is one of the limitations of the multiculturalism model in the life of the Rejang Lebong community.

\section{CONCLUSION}

Based on the results of the interdisciplinary research conducted in Rejang Lebong District related to the high model of multiculturalism and tolerance in the region, it was concluded that the Rejang Lebong community adhered to the foundation of the Indonesian State namely Pancasila and Bhineka Tunggal Ika, besides that there were also relics from their ancestors namely the Rejang Pat Petulai tribe which is a symbol of community unity in the frame of multiculturalism. This reflects the values that are also taught in Islam such as tolerance, help, brotherhood, and deliberation.

KHATULISTIWA: Journal of Islamic Studies Vol. 9, No. 1. March 2019
DOI:

Islamic Integration and Tolerance in Comuunity Behaviour; Multiculturalism Model in The Rejang Lebong District 


\section{BIBLIOGRAPHY}

Ad-Dimasyqi, A.-I. A. (2012). Tafsir Ibnu Kasir. Bandung: Sinar Baru Argensindo.

Anan, A. (2016). MULTIKULTURAN DALAM PRESPEKTIF AL-QUR'AN. al-Murabbi, 1, 273-298.

dalam, R. Z. (2003). In A. D. (ed.), Pendidikan Memang Multikultural: Beberapa Gagasan (p. 23). Jakarta: Safiria Insania Press dan Magister Studi Islam Universitas Indonesia.

Devi, S. (2016). Orang Rejang dan Hukum Adatnya: Tafsiran Atas Kelpeak Ukum Adat Ngen Ca'o Kutei Jang Kabupaten Rejang Lebong. Jurnal Antropologi: Isu-Isu Sosial Budaya, 39-50.

Irsal. (2017). Makna Etis “Punjung Nasi Sawo” Pada Acara Pernikahan Suku Rejang Di Kecamatan Batiknau Kabupaten Bengkulu Utara. Manthiq, 13-26.

Lebong, K. S. (2016). Data Suku Rejang Lebong. Curup: Kantor Statistik R/L.

Moleong, L. J. (2013). Metodologi Penelitian Kualitatif. Bandung: Remaja Rosdakarya.

Mustafa, N. (2014). Multikulturalisme dalam Persfektif Islam. Jurnal Penelitian Keislaman, 28.

Nusantara, Y. B. (1992). Profit Provinsi Republik Indonesia Bengkulu. Jakarta: Pemrakarsa.

Rahman, M. S. (2014). Islam dan Pluralisme. Jurnal Fikrah, 406.

Rusli. (2012). Multikulturalisme dalam Wacana Al-Quran. Studi Islamika, 107.

Sahab. (2017, Maret Minggu). Intervie dengan tokoh adat dan agama Kabupaten Rejang Lebong. (R. Diana, Interviewer)

Setyosari, H. P. (2016). Metode penelitian pendidikan \& pengembangan. Jakarta: Pramedan Media.

Shihab, M. (2002). Tafsir al-Misbah. Jakarta: Lentera Hati.

Syahril, S. (2013). Integrasi Islam dan Multikulturalisme: Persfektif Normatif dan Historis. Jurnal Analisis, 296.

Windiantari, A. (2012). Sejarah Bengkulu. Bekasi: Universal Book.

Yassir, M. (2014). Makna Toleransi dalam Al-Quran. Jurnal Usuluddin, 171.

Zakaria, R. Z. (2003). In A. D. (ed.), Pendidikan Memang Multikultural. Jakarta: Safiria Insania Press dan Magister Studi Islam Universitas Indonesia.

KHATULISTIWA: Journal of Islamic Studies Vol. 9, No. 1. March 2019
DOI:

Islamic Integration and Tolerance in Comuunity Behaviour; Multiculturalism Model in The Rejang Lebong District 